\author{
Jorunn Spord Borgen \\ Norges idrettshøyskole \\ Gunn Engelsrud \\ Høgskulen på Vestlandet
}

DOI: http://dx.doi.org/10.5617/adno.8099

\title{
Språkbruk om kroppsøving: Et kritisk blikk på ny læreplan i Fagfornyelsen (LK20)
}

\begin{abstract}
Sammendrag
I artikkelen analyserer forfatterne læreplan for kroppsøving som faglig og fagpolitisk tekst i læreplanreformen Fagfornyelsen i skolefagene (LK20). Forfatterne sammenligner to tekster, Utdanningsdirektoratets høringsutkast datert mars 2019, og den fastsatte læreplanen for kroppsøving, datert november 2019. På bakgrunn av teori og forskning om læreplaner og forskning om kroppsøving gjennomfører forfatterne en tekstanalyse av disse tekstene og undersøker formuleringer/språkbruk og verb i tekstdelene om fagrelevans, verdier og prinsipper, kjerneelementer (ett), kompetansemål og vurderingstekster. Fra forskningen om læreplaner trekker artikkelen på forskjellen mellom innholdsbaserte og kompetansebaserte læreplanmodeller. I en kompetansebasert læreplanmodell uttrykker verb hva som kan gjøres med et innhold. Innholdet i læreplanen for kroppsøving er i de analyserte tekstene gjerne formulert ved bruk av verb som er omdannet til substantiv. På bakgrunn av analysen diskuterer forfatterne hva det kan innebære for lærerne å skulle operasjonalisere fra planen til undervisning. Forfatterne diskuterer funnene og antyder at lærere kan møte utfordringer i det forestående arbeidet de skal gjøre for å sikre elever læring i fremtidens kroppsøvingsfag i LK20.
\end{abstract}

Nøkkelord: læreplanreform, kroppsøving, læreplanmodeller, verb, kompetansemål

\section{Language use about physical education: A critical look at the new subject curriculum in Norway (LK20)}

\begin{abstract}
Within the context of the Norwegian curriculum renewal reform in school subjects in 2020 (LK20), the authors investigate the curriculum for physical education. The authors compare two texts: the physical education subject curriculum that the Directorate for Education and Training submitted as a consultation draft to teachers, researchers, organisations, and public and private stakeholders in March 2019, and the final curriculum document, concluded in November 2019. Through a text analysis they investigate which formulations/language and verbs are used in the text sections on subject relevance, values and core elements (one), as well as competence goals and assessment texts for physical education. The authors conduct the analysis on the basis of theory and research on curricula, research on physical education and textual analysis. The article draws on curriculum theory on content-based and competence-based
\end{abstract}


curriculum models. In a competence-based curriculum model, verbs express what can be done with a content. The content of the physical education subject curriculum is in the analysed texts formulated by using verbs that are transformed to nouns. Based on the analysis, the authors discuss how teachers can read and operationalise this curriculum. The authors discuss the findings and suggest that teachers may face challenges when deciding how to secure student learning in physical education in LK20.

Keywords: curriculum reform, physical education, curriculum models, verbs, competence goals

\section{Innledning}

Til tross for at det i lang tid har pågått arbeid med læreplanreformen Fagfornyelsen i skolefagene (heretter omtalt som LK20), stiller vi i artikkelen spørsmål om denne Fagfornyelsen bidrar til å gjøre kroppsøvingsfaget mer relevant for fremtiden. Kan vi gjennom en analyse av språket i denne nye læreplanen få øye på fagets relevans og det som skal fornye faget? Selv om skriftspråk i læreplaner ikke er lik undervisning, så tar vi utgangspunkt i at språkbruken i læreplanen også vil komme i bruk i språket i og om faget, og i begrunnelser for praksiser i faget (Sivesind, Afsar \& Bachmann, 2016). Hvis en læreplan skal få betydning for det videre arbeidet lærere skal gjøre i skolen og med undervisning, er det av betydning hvordan den er formulert, med gjennomtenkt språk og begrepsbruk. Dette er vår begrunnelse for å gjennomføre en analyse av språkbruk i kroppsøving i LK20.

Kunnskapsdepartementets (heretter KD) strategi for Fagfornyelsen (KD, 2017) beskriver hvordan arbeidet med å fornye fagene er lagt opp i flere faser. Bred involvering skal bidra til «legitimitet i prosessen, oppslutning om målsettingene for fagfornyelsen og sikre eierskap til det nye læreplanverket» (s. 6). «Fagene skal fornyes av personer med høy faglig og fagdidaktisk kompetanse, og erfaring skal bidra til at læreplanene legger godt til rette for en praksis som er solid forankret i pedagogisk, didaktisk, faglig og empirisk forskning» (s. 5). I artikkelen er vi interessert i hvordan denne prosessen kommer språklig til uttrykk. Vi tar utgangpunkt i en fagorientert lesning av høringsutkastet av læreplanen for kroppsøving datert 18.03.2019 og fastsatt læreplan datert 15.11.2019 (Udir, 2019a, 2019b). Vi bruker disse to versjonene som materiale for å undersøke hvordan fremtidens kroppsøving er formulert i dette fornyelsesarbeidet.

\section{Bakgrunn}

Kroppsøving har tradisjonelt hatt en læreplan på linje med andre fag i skolen. I norsk skole er kroppsøving det eneste av de praktiske og estetiske fagene som alle elever har gjennom alle de 13 årene i opplæringen. Som et av de praktiske og 
estetiske fagene har faget hatt en posisjon som «noe annet» enn norsk og matematikk som har nasjonal eksamen (Borgen \& Hjardemaal, 2017). Det gis standpunktkarakter i faget, og denne teller ved opptak til høyere utdanning. Etter en periode med utprøving av eksamensformer i de praktiske og estetiske fagene har det i 2020 vært en høring om at disse fagene skal bli en del av trekkordningen på ungdomstrinnet med en lokalt gitt muntlig-praktisk eksamen med forberedelsesdel (KD, 2020).

Vi finner lite forskning om kroppsøving i lærerutdanningsforskning, og om undervisning, læring og språkbruk i opplæringen i kroppsøving i norsk skole (Borgen \& Engelsrud, 2015; Jonskås, 2010; Nettverk for forskning på kroppsøving og idrettsfag, 2019). Internasjonalt foreligger mye forskning på kroppsøving med et diskursteoretisk blikk. Denne forskningen får frem at det kan være et misforhold mellom intensjoner og læringsmål i faget, elevers oppfatninger av og erfaringer med faget, samt fagfeltets ideologier og læreres praksiser. Løsningsforslagene støtter seg gjerne på modeller for undervisning med fokus på ulike aspekter av idrett, helse, friluftsliv, personlig utvikling og erfaring, eller øving (Barker, Aggerholm, Standal \& Larsson, 2018; Lindgren \& Barker, 2019). I internasjonal (Kirk, 2010) og nordisk (Annerstedt, 2008; Larsson \& Karlefors, 2018) forskning etterlyses en fornyelse av kroppsøvingsfaget, som et svar på at det å holde elevene aktive blir prioritert, fremfor å videreutvikle deres læring, bevegelseskompetanse og refleksjon (Borgen \& Engelsrud, 2015; Larsson \& Nyberg, 2017; Mattsson, 2016). Flere forskere hevder at elevens laring kommer i bakgrunnen, eller enda sterkere, at det (allment sett) er en manglende forståelse for at kroppsøving i skolen må handle om elevers læring og at det eleven har lært må kunne uttrykkes og være i sentrum for vurderingen (Leirhaug \& Annerstedt, 2016; López-Pastor, Kirk, Lorente-Catalán, MacPhail \& Macdonald, 2013).

Videre trekker vi inn forskningslitteratur om læreplaner og læreplanteori for å belyse læreplantekstene om kroppsøving i forbindelse med Fagfornyelsen. LK20 er en kompetansebasert læreplan. Når vi omtaler henholdsvis innholdsbasert og kompetansebasert læreplan som to ulike modeller, viser dette til et skille som gjøres i politikkutforming og læreplanreformer (OECD, 2018; Borgen, 2018; Borgen, Hallås, Løndal, Moen \& Gjølme, 2020). I sin analyse av Kunnskapsløftet (heretter LK06) som kompetansebasert læreplan, bygger Andreassen (2016) blant annet på Tyler (1999/1949) og får frem hvordan kompetanse i LK06 blir formulert som ferdigheter (handlingsdimensjon) pluss kunnskap (innholdsdimensjon). Elevers handling beskrives i verb, og innholdet i faget i substantiv. I en kompetansebasert læreplan er kompetansemålene formulert med eleven som det handlende subjekt, mens i tidligere, innholdsbaserte læreplaner har undervisningen vært subjekt (Andreassen, 2016, s. 333). I en kompetansebasert læreplan er innholdets status redusert, mens handling, det vil si hva elevene skal kunne 'gjøre' med innholdet som uttrykk for oppnådd kompetanse, er styrket (s. 233). Selv om handling og innhold skal ses i sammenheng i uttrykk for kompetanse, vil innholdskomponenten i målene være svakere uttrykt og være mer generelle i en 
kompetansebasert læreplan. Dette gir lærerne et handlingsrom gjennom operasjonalisering, og i LK06 var dette knyttet til lokalt læreplanarbeid (Andreassen, 2016). Læreplanen åpner da opp for differensiering ved at kompetanse kan vises gjennom ulikt innhold og innholdet kan tilpasses den enkelte elev (Karseth \& Sivesind, 2010). Introduksjonen av den kompetansebaserte læreplantenkingen i LK06 innbar også en vektlegging av elevens selvstendige læring, og var klart inspirert av internasjonale trender (Karseth \& Sivesind, 2010) gjennom samarbeid blant annet i OECD, og av PISA, The Programme for International Student Assessment (Sivesind, 2010). Samtidig ble nasjonale tradisjoner i skolefagene nedtonet (Dale, Engelsen \& Karseth, 2011). Imidlertid trengs læreplaner for å si noe om hvordan den faglige progresjonen kan fastsettes for et utdanningsløp og hvordan et innhold skal velges ut (Sivesind, 2010).

Overgangen fra en innholdsbasert læreplanmodell, slik vi hadde i L97, til en kompetansebasert læreplanmodell, slik vi fikk med læreplanen LK06, har hatt konsekvenser i kroppsøving. Etter læreplanreformen i 2006 har det vært mange diskusjoner, utredninger og flere revisjoner av læreplanen i kroppsøving. Reformen LK06 førte til at det i kroppsøvingsfaget ble rettet kritikk mot at kun elevenes oppnådde kompetanse, og ikke innsats, skulle telle ved vurdering. Ut fra LK06 skal elevene vise kompetanse i kroppsøving gjennom handling, noe som innebærer at de må gjøre noe med egen kropp. Å vurdere kompetanse i denne nye læreplanen viste seg å være utfordrende. Etter en periode med debatt og utredning (Lyngstad, Flagestad, Leirhaug \& Nelvik, 2011) fikk kroppsøving i 2012 som eneste fag i LK06 en forskrift om at innsats skal være med i grunnlaget for vurdering i faget. Det er også blitt fastsatt at tester ikke skal ligge til grunn for karaktersetting i faget (Udir, 2015).

Innsats som substantiv ble innført i læreplanen for kroppsøving for at lærerne skulle kunne vurdere elevenes aktive deltagelse i faget. Forskning om innsats i kroppsøving viser at innsats kobles til aktiviteter som blir synlige for lærerne. Det er hva elevkroppen fremviser som teller som innsats, og forskningen viser at kommunikasjonen rundt innsats gir læreren et maktmiddel overfor elevene (Aasland \& Engelsrud, 2017; Öhman, 2007). Vi vil undersøke om det som i forskningen omtales som misforholdet mellom intensjoner og praksiser i kroppsøving, lar seg forstå bedre gjennom en analyse av språkbruk i kroppsøving i høringsutkastet til læreplan og frem mot fastsatt læreplan LK20. På bakgrunn av reformarbeidet i Fagfornyelsen og forslagene til nye vurderings- og eksamensordninger ser vi behov for mer kunnskap om hva slags språkbruk, terminologi og tenkning om et fag som kroppsøving, som vi får øye på i et slikt reformarbeid. Grunnen til at vi har valgt en slik innfallsvinkel, er at det i forskningslitteraturen, både nasjonalt og internasjonalt, foregår diskusjoner om kroppsøvingsfagets kunnskapsobjekt. Flere forskere har påpekt at kunnskapsobjektet, det felt/fenomen kunnskap i kroppsøving skal omhandle, er uklart, og at spørsmålet om hva som er og skal være fagets kunnskapsobjekt(-er) foreløpig har få gode svar (Annerstedt, 2008; Penney \& Chandler, 2000; Aasland, 2019; Tinning, 2002). 
At et fag har et kunnskapsobjekt, betyr at det er avklart som det fenomen eleven kan (opp)vise kompetanse om. Ifølge strategi for Fagfornyelsen (KD, 2017) skal følgende definisjon av kompetanse ligge til grunn for LK20:

Kompetanse er å tilegne seg og anvende kunnskaper og ferdigheter til å mestre utfordringer og løse oppgaver i kjente og ukjente sammenhenger og situasjoner. Kompetanse innebærer forståelse og evne til refleksjon og kritisk tenkning (s. 5).

I strategien påpekes at «Fagfornyelsen skal gi gode skolefag med relevant innhold» (s. 5, vår utheving), og som nevnt kan læreplanen si noe om hvordan innhold kan velges ut (jf. Sivesind, 2010). Når kunnskapsobjektet som det fenomen kunnskap i kroppsøving skal omhandle, er relatert til innhold og handling, gir dette et vidt tolkningsrom for operasjonalisering. Når kunnskapsobjekter ikke er et produkt (som en tekst, et musikkstykke, en tegning), men elevens egne bevegelser, må disse operasjonaliseres som kunnskapsobjekter for å kunne vurderes. For eksempel kan det «å kunne bruke kart og kompass» være kunnskapsobjekt, eller det «å kunne bevege seg ute i et landskap og bruke kart og kompass», eller «å kunne planlegge tur ved hjelp av kart og kompass og gjennomføre turen», osv. Når materiell som kart og kompass inngår, kan det synes 'enklere' for læreren som kan observere aktiviteten, men selv dét krever operasjonalisering. Som i eksemplet her: å kunne bruke kart og kompass innebærer også å forstå retning, avstand og å få en kroppslig læring ved å bruke disse epistemiske objekter/artefakter i ulike kontekster. Det vi kommer tilbake til gjennom artikkelen er utfordringer i kroppsøving der læreren skal vurdere ulike fenomener som kompetanse, når eleven samtidig er det personlige kroppssubjektet som skal vise denne kompetansen. Når LK20 representerer en videreføring av en kompetansebasert læreplanmodell, er verb språklig sett viktige for å kommunisere hva elevene skal vise som kompetanse gjennom ferdigheter (handlingsdimensjon) pluss kunnskap (innholdsdimensjon). Vi retter på denne bakgrunn også oppmerksomheten mot verbene i læreplantekstene.

\section{Problemstilling}

Vi har utformet følgende overordnede problemstilling:

Hva slags språk om kroppsøving får vi øye på gjennom en tekstanalyse av høringsutkastet og fastsatt lcereplan LK20?

Problemstillingen er videre operasjonalisert til to spørsmål:

A: Hvordan formuleres kroppsøving i punktene fagrelevans, verdier og kjerneelementet «Bevegelse og kroppslig laring» i de to lcereplantekstene?

B: Hvilke generelle og fagspesifikke verb brukes i overordnet del og $i$ kompetansemålene samt i vurderingstekstene i de to læreplantekstene? 


\section{Læreplan, språk og handling}

Læreplanlitteraturen tilsier at det er behov for kunnskap om planlegging av læring i skolen, og om hvordan læreplaner kan operasjonaliseres av lærere og gjøres om til undervisning. Å operasjonalisere innebærer å kunne gjøre bruk av læreplantekster som et grunnlag for undervisningspraksiser. Dersom læreplanen forstås som noe som skal 'implementeres', kan det føre til at lærerne blir opptatt av instruksjon og mister blikket for at elevenes læring språkliggjøres i dynamiske og åpne prosesser (Schwartz, 2006). Slik Dale (2008, s. 94) formulerer seg, ligger forutsetningene for skolefaglig læring i at språk og handling utvikles sosialt og i sammenheng med innholdet. Å utvikle og ha felles språkbruk er vesentlig for at elevene etter hvert kan delta i abstrakte fellesskap innenfor et fagområde. I tråd med Andreassen (2016) forstår vi formelle læreplantekster som politiske og normative tekster, og som bygget inn i sosial og faglig meningsproduksjon. Når elevers læring er målet for utdanningspolitikken, er veien fra intendert til realisert læreplan kompleks og skal gjennom mange fortolkningsledd. Resultatet i form av undervisning i klasserommet er avhengig av at språket er meningsfullt og fungerer i kommunikasjonen mellom elever og lærere (Skrede, 2017).

Kunnskapsdepartementet (KD) har utarbeidet Retningslinjer for læreplangruppene (KD, 2018), som fungerer formativt for hvordan Fagfornyelsen som politisk idé blir utformet som tekster av læreplangruppene for fagene, og for hvordan disse tekstene danner grunnlag for videre tolkning og operasjonalisering i skolen. Ifølge retningslinjene skal de nye læreplanene «være gode verktøy for støtte og styring for lærere, skoleledere og skoleeiere. Læreplanene skal legge til rette for varierte undervisningsformer og vurderingsmåter som fremmer dybdelæring» (s. 2). Videre skal læreplanen omfatte korte beskrivelser av fagets relevans, herunder beskrivelser av "på hvilke måter faget er relevant for den enkelte eleven eller lærlingen, og på hvilke måter faget er relevant i et bredt samfunns- og arbeidslivsperspektiv» (s. 4). Læreplanene skal være tredelte: Først en overordnet del som handler «om faget» og omfatter omtale av fagets relevans, kjerneelementer, fagspesifikk tekst om verdier og prinsipper i overordnet del, tverrfaglige temaer og grunnleggende ferdigheter. Del to består av kompetansemål for årstrinn, og del tre omhandler tekster om vurdering som etterfølger kompetansemålene på årstrinn. Del én og to skal ses i sammenheng i de to læreplantekstene som utgjør vårt datagrunnlag.

\section{Metode og datagrunnlag}

For å belyse spørsmålene vi har stilt, arbeider vi med en tekstanalytisk metode (Fauskanger \& Mosvold, 2014; Bratberg, 2017). Vi har avgrenset undersøkelsen til hvordan setninger gir «fullverdig tilgang til mening» (Bratberg, 2017, s. 15) og til grammatiske forhold, som bruk av verb og formuleringer internt $\mathrm{i}$ 
læreplantekstene, sammenhengene mellom de ulike delene i tekstene og likheter og ulikheter mellom høringsutkastet og fastsatt læreplan. Vi trekker deretter inn kunnskap fra forskning i kroppsøving og læreplanteoretisk forskning i drøftingen. Vi arbeidet med tekstene ut fra det Johannessen, Witsø Rafoss og Børve Rasmussen (2018, s. 39) kaller en «spørsmålsdrevet analyseprosess», der vår fremgangsmåte var å lese høringsutkastet og fastsatt læreplan i kroppsøving mange ganger og diskutere, notere og stille spørsmål hver for oss og sammen, som en hermeneutisk tolkende prosess (Thomassen, 2020).

Vi leste tekstene om «Fagrelevans for eleven/lærlingen, samfunnet og arbeidslivet» som den sentrale begrunnelsen for at kroppsøving er et fag i opplæringen. Hvordan dette videre blir fremskrevet i disse læreplantekstene, gir innblikk i språkbruk og fagterminologi som skal bidra til å fornye faget. Videre gjennomførte vi en analyse av verb i de to læreplantekstene, der vi undersøkte forekomst av både generelle og fagspesifikke verb. Vi tok utgangspunkt i Retningslinjer for læreplangruppene (KD, 2018) og den delen av retningslinjene som omhandler «verblesning», som også omfatter en liste over generelle verb, med definisjoner av verbene, til bruk for læreplangruppene. Denne teksten er på bokmål. Når vi har identifisert fagspesifikke verb, har vi gjort dette i relasjon til innhold slik det fremstår i læreplantekstene, som er på nynorsk. Hvordan fagspesifikke verb blir brukt, relaterer vi til innhold i tidligere læreplaner og forskningslitteraturen i kroppsøving.

I fortsettelsen gjør vi rede for resultater i relasjon til problemstillingene og perspektivene vi har trukket inn fra forskning. Utledet fra hovedproblemstillingen, der vi spurte hvilket språk vi får øye på gjennom en tekstanalyse av høringsutkastet og fastsatt læreplan for kroppsøving, gjør vi språklige analyser av punktene fagrelevans, verdier og kjerneelementet «Bevegelse og kroppslig læring», samt verbanalyse av kompetansemålene og vurderingstekstene. Vi observerer at høringsutkastet er utformet på grunnlag av Retningslinjer for læreplangruppene (KD, 2018), mens fastsatt læreplan har noen endringer i struktur sammenlignet med høringsutkastet. Vi har valgt å følge oppsettet i fastsatt læreplan i redegjørelsen for resultater. Videre gjør vi oppmerksom på at selv om læreplanen for kroppsøving i høringsutkastet og fastsatt læreplan er på nynorsk, er det flere eksempler på at samme ord i de to tekstene forekommer i ulike varianter. Eksempler er fremjar/fremjer og skapar/skaper. Vi har valgt å gjengi tekstene ordrett.

\section{Språk i læreplanen}

\section{«Fagrelevans og sentrale verdiar»}

Denne delen av læreplanen har to avsnitt. Vi foretar først en analyse av det første avsnittet om fagets relevans, og deretter av andre avsnitt om hvordan faget bidrar 
til å realisere verdigrunnlaget for opplæringen. Tekstboks 1 viser hvordan avsnittet om fagrelevans for eleven/lærlingen, samfunnet og arbeidslivet er formulert:

Tekstboks 1. Fagrelevans - i høringsutkast og fastsatt læreplan

\begin{tabular}{|l|l|}
\hline $\begin{array}{l}\text { Fagrelevans - } \\
\text { høringsutkast }\end{array}$ & $\begin{array}{l}\text { Kroppsøvingsfaget skal medverke til at elevane sansar, opplever, lærer og skapar } \\
\text { med kroppen. Bevegelse er grunnleggjande hos mennesket og har eigenverdi. } \\
\text { Kroppsøving skal stimulere til ein fysisk aktiv livsstil og bevegelsesglede. Det } \\
\text { sosiale aspektet ved bevegelsesaktivitet og naturferdsel saman med andre gjer } \\
\text { kroppsøving til ein viktig arena for å fremje samarbeid, forståing og respekt for } \\
\text { kvarandre. Gjennom kroppsøvingsfaget skal elevane få kunnskap om trening, } \\
\text { livsstil og helse og erfaring med kva eigen innsats har å seie for å oppnå mål. } \\
\text { Faget skal motivere elevane til å halde ved like ein fysisk aktiv og } \\
\text { helsefremjande livsstil etter avslutta skulegang og i framtidig arbeidsliv. }\end{array}$ \\
\hline $\begin{array}{l}\text { Fagrelevans - } \\
\text { fastsatt } \\
\text { læreplan }\end{array}$ & $\begin{array}{l}\text { Kroppsøving er eit sentralt fag for å stimulere til livslang bevegelsesglede og til } \\
\text { ein fysisk aktiv livsstil ut frå eigne føresetnader. Faget skal bidra til at elevane } \\
\text { lærer, sansar, opplever og skaper med kroppen. Gjennom bevegelsesaktivitet og } \\
\text { naturferdsel saman med andre fremjer kroppsøving samarbeid, forståing og } \\
\text { respekt for kvarandre. Faget skal bidra til at elevane utvikler kompetanse om } \\
\text { trening, livsstil og helse og erfarer kva eigen innsats har å seie for å oppnå mål. } \\
\text { Innsatsen til elevane er derfor ein del av kompetansen i kroppsøving. Faget skal } \\
\text { motivere elevane til å halde ved like ein fysisk aktiv og helsefremjande livsstil } \\
\text { etter avslutta skulegang og i framtidig arbeidsliv. }\end{array}$ \\
\hline
\end{tabular}

I tekstene om fagrelevans er faget gjennomgående brukt som subjekt i setningene (jf. Andreassen, 2016). Faget er det som skal medvirke/bidra til at eleven skal sanse, oppleve, lære og skape med kroppen. I tekstene gis med andre ord faget en rolle som det som kan gjøre noe med elevene. Samtidig blir kroppen omtalt som noe elevene «sansar, opplever, lærer og skapar» med (jf. høringsutkastet).

Vi legger merke til at det er foretatt en viss omskriving og ommøblering av utsagn mellom de to tekstene. I høringsutkastet er bevegelse omtalt som «grunnleggjande» hos mennesket, og har «eigenverdi». Dette utsagnet er tatt ut av fastsatt læreplantekst. Videre i tekstene om fagrelevans brukes begrepene «aktiv livsstil» og «bevegelsesglede» som noe faget skal stimulere til, som om disse var kunnskapsobjekter. Det kommer ikke frem hvorvidt bevegelsesglede er noe elevene skal lære om eller om det er en følelse de skal få, eller noe de skal bli og leve etter (i fremtiden). Faget skal imidlertid stimulere til aktiv livsstil og føre til bevegelsesglede. Det sosiale omtales i tekstene som et aspekt elevene skal erfare gjennom å gjøre aktivitetene. Her blir faget omtalt som en arena for sosial deltagelse der aktiviteten kommer i forgrunnen.

Når det gjelder trening, livsstil og helse, er det ulikheter mellom høringsutkastet og fastsatt læreplan. Endringene handler om elevene. Ifølge høringsutkastet skal elevene gjennom kroppsøvingsfaget få kunnskap om «trening, livsstil og helse og erfaring med kva eigen innsats har å seie for å oppnå mål» (vår utheving). I fastsatt læreplan skal elevene utvikle kompetanse om de samme fenomenene, og erfaring som substantiv er byttet ut med erfare som verb.

I begge læreplantekstene er innsats formulert som innhold i faget, og elevene skal forstå at innsats har noe å si for å oppnå mål. Et fremtredende trekk i 
høringsutkastet og fastsatt læreplan er at faget skal medverke, skal stimulere, fremje, skal motivere.

Utsagnet «Innsatsen til elevane er derfor ein del av kompetansen i kroppsøving» er nytt i fastsatt læreplan. Vi spør om innsats er blitt et kunnskapsobjekt siden det inkluderes i denne teksten og fremstår som en overordnet kompetanse i kroppsøving. Handlingen å vise innsats virker da å være svakt koblet til innhold, og dette gir læreren stort tolkningsrom.

\section{Verdier}

I følge Retningslinjene for læreplangruppen (KD, 2018) er dette en fagspesifikk tekst som skal beskrive hvordan verdier og prinsipper i overordnet del av Fagfornyelsen er synliggjort i faget. Tekstboks 2 viser tekstene om verdier i kroppsøving:

Tekstboks 2. Verdier - i høringsutkast og fastsatt læreplan

\begin{tabular}{|l|l|}
\hline $\begin{array}{l}\text { Verdier - } \\
\text { høringsutkast }\end{array}$ & $\begin{array}{l}\text { Bevegelseskultur i form av leik, friluftsliv, dans, symjing, idrettsaktivitetar og } \\
\text { andre bevegelsesaktivitetar er ein del av den felles danninga og identitetsskapinga } \\
\text { i samfunnet. Kroppsøving tek vare på tradisjonell bevegelsesaktivitet i samfunnet, } \\
\text { men stimulerer òg til eksperimentering og kreativ utfalding i alternative } \\
\text { bevegelsesformer. Faget utfordrar elevanes mot til å tøye eigne grenser. Kropps- } \\
\text { øving fremjar kritisk tenking omkring kroppsideal og bevegelseskulturar som kan } \\
\text { påverke sjølvkjensle, helse, trening og livsstil. Uteaktivitet og naturferdsel gir } \\
\text { grunnlag for naturglede, respekt for naturen og miljømedvit. I kroppsøving skal } \\
\text { elevane løyse utfordringar og oppgåver i eit mangfaldig læringsfellesskap. } \\
\text { Kroppsøving gir elevane høve til å praktisere og reflektere over samspel, med- } \\
\text { verknad, likestilling og likeverd på ulike måtar. }\end{array}$ \\
\hline $\begin{array}{l}\text { Verdier - } \\
\text { fastsatt } \\
\text { læreplan }\end{array}$ & $\begin{array}{l}\text { Alle fag skal bidra til å realisere verdigrunnlaget for opplæringa. Kroppsøving } \\
\text { skal bidra til å gi elevane høve til å praktisere og reflektere over samspel, med- } \\
\text { verknad, likestilling og likeverd. I kroppsøving skal elevane løyse utfordringar og } \\
\text { oppgåver i eit mangfaldig læringsfellesskap. Faget skal òg utfordre motet deira til } \\
\text { å tøye eigne grenser. Leik, friluftsliv, dans, symjing, idrettsaktivitetar og andre } \\
\text { bevegelsesaktivitetar er ein del av den felles danninga og identitetsskapinga i sam- } \\
\text { funnet. Kroppsøving tek vare på tradisjonell bevegelsesaktivitet i samfunnet, men } \\
\text { stimulerer òg til eksperimentering og kreativ utfalding i alternative bevegelses- } \\
\text { former. Kroppsøving fremjar kritisk tenking omkring kroppsideal som kan } \\
\text { påverke sjølvkjensle, helse, trening og livsstil. Uteaktivitet og naturferdsel gir } \\
\text { grunnlag for naturglede, respekt for naturen og miljømedvit. }\end{array}$ \\
\hline
\end{tabular}

En sentral verdi i høringsutkastet er at bevegelseskultur får status ved at det å gjennomføre aktiviteter (i form av leik, friluftsliv, dans, symjing, idrettsaktivitetar og andre bevegelsesaktivitetar) blir del av identitetsskaping på samfunnsnivå. I fastsatt læreplan observerer vi at begrepet bevegelseskultur er tatt ut. Her er det i stedet lagt vekt på at bevegelsesaktiviteter tar vare på «tradisjonell bevegelsesaktivitet i samfunnet». Videre skal faget også stimulere til «eksperimentering og kreativ utfalding» og utfordrer / skal utfordre «mot/et til å tøye eigne grenser.» I fastsatt læreplan brukes ulike verbtider.

I høringsutkastet hevdes at «kroppsøving fremjar kritisk tenking omkring kroppsideal og bevegelseskulturar som kan påverke sjølvkjensle, helse, trening 
og livsstil.» Her gis faget status som det som fremmer, og faget får til at elever lærer å tenke kritisk omkring slike tema, som igjen skal påvirke «sjølvkjensle, helse, trening og livsstil».

Vi legger merke til at det også her er foretatt en ommøblering av til dels like utsagn mellom de to læreplantekstene. Vi observerer at bestemte aktiviteter beskrives som å gi grunnlag for bevegelsesglede og naturglede i faget. Vi spør om hva som her kan være kunnskapsobjekter, i betydningen at det er avklart som et fenomen eleven kan vise kompetanse om i faget i denne sammenhengen, og hvordan læreren skal vurdere det.

\section{Kjerneelementet «Bevegelse og kroppsleg læring»}

Vi har valgt ut «Bevegelse og kroppsleg læring», ett av kjerneelementene, for nærmere analyse. Begrepet «kroppslig læring» er nytt i læreplanen. Lærere forventes å operasjonalisere kompetansemålene i relasjon til forståelsen av kjerneelementene. Tekstboks 3 viser teksten om dette kjerneelementet:

Tekstboks 3. Kjerneelementet Bevegelse og kroppslig læring. Høringsversjon og fastsatt versjon er like

\begin{tabular}{|l|}
\hline Kjerneelementet Bevegelse og kroppslig læring. (Høringsutkast og fastsatt læreplan er like) \\
\hline Elevane skal bli kjende med å vere i bevegelse åleine og saman med andre ut frå eigne interesser, \\
intensjonar og føresetnader. Elevane utforskar eigen identitet og eige sjølvbilete, og reflekterer over \\
og tenkjer kritisk om samanhengane mellom bevegelse, kropp, trening og helse. Kroppsøving gir \\
rom for kroppsleg læring gjennom leik og øving i friluftsliv, dans, idrettsaktivitetar og andre \\
bevegelsesaktivitetar. Kroppsleg læring handlar om allsidig motorisk læring, utvikling av kropps- \\
medvit og stimulering til bevegelsesglede.
\end{tabular}

Først skal elevene «bli kjende med å vere i bevegelse». Neste setning viser at identitet og selvbilde skal utforskes. Med verbet «utforskar» viser teksten til noe elevene må gjøre som handling for å vise kompetanse om «identitet og sjølvbilete». Vi spør hva som kan være kunnskapsobjektet her, når disse tematikker skal utforskes av elevene og læreren skal vurdere det.

Neste setning påpeker at «elevane reflekterer over og tenkjer kritisk om samanhengane mellom bevegelse, kropp, trening og helse». Teksten sier at det allerede foregår handlinger av denne art hos elevene. Videre sies det at kroppsøving gir rom for kroppslig læring, og det listes opp aktiviteter som faller inn under dette. Kunnskapsobjektet kan her bli de ulike aktivitetene som definerer innholdet i kroppslig læring, det vil si «leik og øving i friluftsliv, dans, idrettsaktivitetar og andre bevegelsesaktivitetar». Vi spør om «kroppsmedvit» og «stimulering til bevegelsesglede» er noe som kommer i tillegg, og om det også skal gjelde som et kunnskapsobjekt, og hvordan læreren skal vurdere det.

Samlet sett ser vi i analysen av de tre tekstdelene av høringsutkastet og fastsatt læreplan at faget er subjektet som gjør noe, og følgende verb blir brukt til å uttrykke dette: er, gir, gir rom, gir grunnlag for, gir høve til, fremjar, medverkar, motiverer, skal, skal bli, stimulerer, påverkar, tek vare på, tøyer, utfordrar / skal utfordre. I fastsatt læreplan omtales elevene som de som lærer, løyser 
(utfordringar og oppgåver), utforskar, reflekterer og tenkjer kritisk. I det følgende undersøker vi verb brukt i læreplanen.

\section{Verbbruk i læreplanen}

I analysen av verb i læreplanen i kroppsøving spør vi: Hvilke generelle og fagspesifikke verb brukes i overordnet del og i kompetansemålene samt vurderingstekstene i læreplanen? Nedfor presenterer vi hva vi har kommet frem til i arbeidet med å skaffe oss oversikt over bruken av - og plasseringen av - verbene i læreplanens ulike deler, se tabellene 1, 2, 3 og 4 . Vi observerer en del endringer i verbbruk fra høringsutkastet til fastsatt læreplan i kroppsøving, og at vurderingstekstene i fastsatt læreplan til dels består av standardiserte utsagn som går igjen etter hvert trinn i læreplanen, for eksempel «Elevane skal få høve til å prøve seg fram».

\section{Generelle verb}

I verblisten vedlagt Retningslinjer for læreplangruppene (KD, 2018) er det til sammen 18 verb, se tabell 1 :

Tabell 1. Generelle verb (fra verbliste, KD, 2018)

\begin{tabular}{|l|l|}
\hline $\begin{array}{l}\text { Generelle } \\
\text { verb }\end{array}$ & $\begin{array}{l}\text { Analysere, anvende, beskrive, bruke, dokumentere, drøfte, forstå, gjennomføre, gjøre } \\
\text { rede for, planlegge, presentere, reflektere, samarbeide, sammenligne, tolke, utforske, } \\
\text { utvikle, vurdere. }\end{array}$ \\
\hline
\end{tabular}

De generelle verbene analysere, anvende, dokumentere, samarbeide og sammenligne brukes ikke i læreplantekstene for kroppsøving. Drøfte, gjøre rede for og tolke brukes én gang. Presentere brukes i ett kompetansemål på 10. årstrinn: «presentere dansekomposisjonar». Vi har sett nærmere på de generelle verbene i tabell 2:

Tabell 2. Generelle verb (fra verbliste, KD, 2018) i høringsutkast og i fastsatt læreplan

\begin{tabular}{|l|l|l|}
\hline \multirow{2}{*}{ Generelle verb } & I høringsutkast 18.03.2019 & I fastsatt læreplan 15.11.2019 \\
\cline { 2 - 3 } & Antall & Antall \\
\hline Bruke & 16 & 28 \\
\hline Forstå/forståing & 16 & 19 \\
\hline Gjennomføre & 18 & 20 \\
\hline Reflektere & 14 & 16 \\
\hline Utforske & 23 & 12 \\
\hline Utvikle & 23 & 16 \\
\hline
\end{tabular}

Utforske er det av de generelle verbene ${ }^{1}$ som er brukt mest i høringsutkastet til læreplan for kroppsøving (23 ganger), se tabell 2. I overordnet del er verbet brukt

\footnotetext{
${ }^{1}$ Som generelt verb er utforske i verblisten fra KD (2018) definert som: «Å utforske handler om å oppleve og eksperimentere og kan ivareta nysgjerrighet og undring. Å utforske kan bety å sanse, søke, oppdage, observere
} 
6 ganger. Utforske skal ifølge høringsutkastet foregå i faget på årstrinnene 2, 4, 7, 10 og Vg1. I vurderingstekster brukes verbet imidlertid for 2. og 4. årstrinn samt Vg1, Vg2 og Vg3. Denne ubalansen mellom kompetansemål og vurderingstekster er tydelig på 2. årstrinn der elevene skal utforske og gjennomføre, bruke kroppen til å utforske, utforske og øve, og utforske uteaktivitetar. Av disse formene for utforskning er kun utforske uteaktiviteter nevnt i vurderingsteksten. I fastsatt læreplan er verbet å utforske brukt 12 ganger. Vi observerer at å utforske er noe som skal foregå, og kan forstås som arbeidsmåte i aktiviteter.

Utvikle er også brukt 23 ganger i høringsutkastet, oftest i sammenheng med å utvikle kompetanse, omtalt 18 ganger i vurderingstekstene. Her er det ikke elevene som utvikler noe, men lærernes blikk på elevens utvikling som omtales. I fastsatt læreplan er verbet å utvikle brukt 16 ganger, hvorav 9 i kompetansemålene på trinnene 1-10.

Når det gjelder verbene utforske og utvikle, har det altså skjedd en reduksjon i antall ganger verbene brukes, fra høringsutkastet til fastsatt læreplan. Mens bruke fins 16 ganger i høringsutkastet, fins det 28 ganger i fastsatt læreplan, hvorav 23 ganger i kompetansemål og vurderingstekster. I kompetansemålene i fastsatt læreplan skal elevene blant annet bruke kroppen, basisferdigheter, kart etc., regler, nærmiljøet. I tekstene om underveisvurdering står følgende standardsetning: «Læraren skal gi rettleiing om vidare læring og tilpasse opplæringa slik at elevane kan bruke rettleiinga for å utvikle kompetansen sin i [...]» (vår utheving).

\section{Fagspesifikke verb}

De fagspesifikke verbene, hvorav noen også er substantiverte verb, er verb vi ut fra lesningene våre har kategorisert som særlig relatert til faget, og vi har identifisert 31 slike verb, se tabell 3.

Tabell 3. Fagspesifikke verb i høringsutkast og fastsatt læreplan

\begin{tabular}{|l|l|}
\hline Fagspesifikke verb (også substantiverte) i høringsutkast & $\begin{array}{l}\text { Nye fagspesifikke verb (også } \\
\text { substantiverte) i fastsatt læreplan }\end{array}$ \\
\hline $\begin{array}{l}\text { Avlevere, delta/deltaking, dykke, gjere, gå, flyte, forvalte } \\
\text { (helse), føre (ball), hinke, hoppe, inkludere (alle, kvarandre), } \\
\text { kaste (ball), krype, lande, leike, løyse (utfordringar), med- } \\
\text { verke, orientere (seg), praktisere, rulle, samspel, satse, } \\
\text { sprette, springe, svømme, trene, tøye, utføre, øve. }\end{array}$ & \\
\hline
\end{tabular}

Flere av disse verbene er nevnt 1 til 3 ganger, for eksempel i kompetansemål på årstrinn 2 og 4, angående svømming. Noen av de fagspesifikke verbene brukes også som substantiverte verb i tekstene, for eksempel oppleve/oppleving, delta/ deltaking. Samspel som substantivert verb er mye brukt i begge tekstene. En formulering som går igjen er: «Samspel med andre, øving og deltaking i ulike bevegelsesaktivitetar og naturferdsel er vesentlege trekk ved kompetansen i

og granske. I noen tilfeller betyr det å undersøke ulike sider av en sak gjennom åpen og kritisk drøfting. Å utforske kan også bety å teste eller prøve ut og evaluere arbeidsmetoder, produkter eller utstyr». 
kroppsøving.» Vi har på denne bakgrunn inkludert samspel blant oversikten over fagspesifikke verb/substantiverte verb, se tabell 4 .

Tabell 4. Fagspesifikke verb (og substantiverte verb) i høringsutkast og fastsatt læreplan. Et utvalg.

\begin{tabular}{|l|c|l|}
\hline Fagspesifikke verb & I høringsutkast 18.03.2019 & I fastsatt læreplan 15.11.2019 \\
\hline Delta/deltaking & 23 & 17 \\
\hline Medverke & 7 & 7 \\
\hline Oppleve/oppleving & 0 & 9 \\
\hline Praktisere & 6 & 7 \\
\hline Prøve & 0 & 11 \\
\hline Samspel & 13 & 21 \\
\hline Øve & 24 & 11 \\
\hline
\end{tabular}

Delta/deltaking inngår i høringsutkastet 3 ganger i overordnet del, 3 ganger i kompetansemål, og 17 ganger i vurderingstekstene på alle trinn. Det er læreren som skal vurdere elevenes deltagelse, mens det er uklart hva elevene skal oppnå med deltagelsen. I fastsatt læreplan er verbet delta brukt 4 ganger og deltaking som substantivert verb 13 ganger, oftest angående vurdering.

Øve er det hyppigst brukte fagspesifikke verbet (24 ganger) i høringsutkastet av læreplanen. Det er brukt 1 gang i overordnet del, 7 ganger i kompetansemålene, samt 15 ganger i tekster om vurdering. Ifølge vurderingstekstene skal læreren vurdere elevens øving: «Vurderinga skal motivere elevane til å delta og halde fram med å øve òg når det ikkje gir resultat i prestasjon eller ferdigheitsutvikling. Læraren må hjelpe elevane til å sette ord på kva dei får til og kva dei treng å øve meir på for å kunne veilede elevane ut frå deira eigne føresetnader.» I fastsatt læreplan er verbet brukt 11 ganger, 1 gang under demokrati og medborgerskap, videre i kompetansemålene for 2., 4., 7. og 10. trinn samt Vg3. Formuleringen «[...]halde fram med å øve òg når det ikkje gir resultat[...]» er tatt ut. Vi observerer her en ubalanse mellom kompetansemål og vurderingstekster i bruk av verbet øve, ved at verbet forekommer på mange av trinnene i kompetansemål, men i vurderingstekstene kun for Vg1 og Vg3.

Verbet prøve er nytt i fastsatt læreplan. Det brukes 11 ganger, kun i vurderingstekstene på alle trinn, og synes i de fleste tilfeller å erstatte verbet øve fra høringsutkastet. En formulering som går igjen i vurderingstekstene, er at «elevane skal få høve til å prøve seg fram». Det er læreren som skal vurdere elevenes prøving, mens det er uklart hva elevene skal oppnå med prøvingen.

Verbet oppleve er nytt i fastsatt læreplan, der det brukes 9 ganger, i alle underveisvurderingstekstene formulert som: «Med utgangspunkt i kompetansen elevane viser, skal dei få høve til å setje ord på kva dei opplever at dei får til, og reflektere over si eiga faglege utvikling» (vår utheving). I tillegg brukes naturoppleving 7 ganger som substantiv om det å oppleve naturen.

Praktisere brukes ganske likt i høringsutkastet og i fastsatt læreplan. I overordnet del sies det at «kroppsøving skal bidra til å gi elevane høve til å praktisere og reflektere over samspel, medverknad, likestilling og likeverd». Verbet brukes deretter oftest i kompetansemål om å praktisere regler, og på Vg2 om «å praktisere 
berekraftig ferdsel». Vi observerer at verbet praktisere brukes både overordnet om de overordnede verdiene i faget, og mer instrumentelt når det gjelder for eksempel å praktisere regler.

I fortsettelsen diskuterer vi funnene. Vi organiserer diskusjonen ut fra hvordan funnene belyser problemstillingen om hvilket språk vi får øye på om kroppsøving som et skolefag i høringsutkastet og fastsatt læreplan (LK20).

\section{Diskusjon}

\section{Handling og innhold i læreplanen}

Vi går tilbake til at Fagfornyelsen skal være en kompetansebasert læreplan, der kompetansemålene er formulert med eleven som det handlende subjekt, til forskjell fra tidligere innholdsbaserte læreplaner hvor undervisningen har vært subjekt (jf. Andreassen, 2016). Et kompetansemål kan på denne bakgrunn ikke fungere uten at det er mulig for læreren å se for seg og utvikle kriterier for hvordan hen kan skape læringserfaringer hos elevene, og vurdere noe hen kan være rimelig sikker på er kompetanse hos elevene (jf. Tyler, 1999/1949; Andreassen, 2016). Om elevene skal lære å løpe, kan et kriterium være at de skal kunne løpe 60 meter på bestemt tid. Da må elevene være i stand til å gjøre noe ut fra en standard (Prøitz, 2015, s. 46). Da er kunnskapsobjektet 60-meteren. Dette er noe annet enn om kunnskapsobjektet er en elevs utforskning, refleksjon og egen opplevelse av å ha blitt en bedre løper. Når kunnskapsobjektet er elevens egen subjektive utforskning av å ha blitt en bedre løper, vil det kreve et arbeid å finne ut hvordan læreren skal vurdere dette som erfaring hos eleven. Disse kriteriene skal være forståelige for elevene slik at de vet hvilke mål de arbeider mot. I verbanalysen vår viser det seg at verbene som skal vise handling, ofte er substantivert. Når for eksempel utforskning er substantiv, er det blitt innhold og ikke handling. Det kan dermed bli uklart hva eleven skal gjøre for å vise oppnådd kompetanse, samt hva læreren skal vurdere.

Blant de fagspesifikke verbene i høringsutkastet er øve særlig bemerkelsesverdig. «Øve» er i den norske bokmålsordboken (Øve, 2020) synonymt med å trene (øve opp og utvikle), innøve, oppøve noe, og refleksivt øve for å videreutvikle, forbedre, øve opp igjen. Med andre ord; du øver på noe, det er et før, underveis og etter øvingen, som gir mening, læring og utvikling for den som øver, og som i kroppsøving blant annet vil kunne være å oppdage ulike kvaliteter og variasjonsmuligheter i bevegelsene. Øving slik det beskrives i høringsutkastet, «delta og halde fram med å øve òg når det ikkje gir resultat i prestasjon eller ferdigheitsutvikling» kan fortone seg som å fortsette med noe uten at det verken gir mening, fører til endring eller til ny kunnskap. Hvis eleven er subjekt, blir dette et lite meningsfylt øvingsbegrep. Som nevnt er formuleringen endret i fastsatt læreplan, der øve er erstattet av formuleringen «høve til å prøve» i 
vurderingstekstene. Imidlertid gir ikke denne formuleringen mer informasjon om hva som kan være kunnskapsobjektet i forbindelse med øving og prøving. Når formuleringen høve til å prøve gjentas i vurderingstekstene, gir dette læreren i oppgave å operasjonalisere kriterier for, se og vurdere om det øves og prøves. Det kan bli uavklarte forhold angående hva eleven skal gjøre når hen får høve til å prøve, med hvilket innhold, for å vise hvilken oppnådd kompetanse, samt hva læreren skal vurdere. Dette er et eksempel på det forskningslitteraturen vi har vist til innledningsvis, omtaler som fagets uklare kunnskapsobjekt, og slike uklarheter kan se ut til å opprettholdes i LK20.

\section{Språket om kroppsøvingsfaget}

Som vi har tatt opp innledningsvis, har språk sosial mening og språket er læreplanens virkemiddel og kommunikasjonsform. Det vi har fått frem i analysen, er at språkbruk kan gi rom for mange tolkninger og peke i ulike retninger. Vi har avdekket et språk om kroppsøving i Fagfornyelsen som er gjenkjennelig både fra forskningslitteraturen og fra vår egen undervisning i lærerutdanningen. Den språklige uklarheten som forskningen omtaler at fins i kroppsøving, uttrykkes særlig ved substantiverte verb. Substantivering av verb innebærer ifølge Skrede (2017 s. 115) å tingliggjøre prosesser ved hjelp av substantiv, og på den måten fjerne handlende subjekter og menneskelige forhold, og med det ansvaret for gjennomføring og etiske valg. Et substantivert verb endrer meningen fra det 'å handle' til å bli et objekt/innhold. Dette kan være et problem i kroppsøving. Eksempler i læreplantekstene er at verbene å utforske blir til utforskning og å samspille eller spille sammen blir til samspill. Substantivering av verb endrer meningen fra det å gjøre en handling til at det beskriver et objekt/innhold i faget. $\AA$ danse blir til dans, å bevege seg blir til bevegelse, å velge blir til valg. Dette svarer til at undervisningen er subjektet i en innholdsbasert læreplanmodell (jf. Andreassen, 2016), og skaper uklarhet om hva som er handling og hva som er innhold når elevene skal vise kompetanse i en kompetansebasert læreplan.

På den andre side, når bevegelse omtales som handling, blir det logisk å betrakte bevegelse som kompetanse i en kompetansebasert læreplan; altså at eleven kan bruke bevegelser de lærer i kroppsøving, og at disse vurderes kvalitativt i sammenheng med innholdet og konteksten for bevegelsen. Det er imidlertid ingen kompetansemål som klart indikerer at elevene skal vise slike kompetanser. Et eksempel er et kompetansemål på 2. årstrinn: «utforske og gjennomføre grunnleggjande bevegelsar som å krype, gå, springe, hinke, satse, lande, vende og rulle i ulike miljø ut frå eigne føresetnader». Dette er bevegelsesmåter alle barn kan når de kommer til skolen, men potensialet barn bringer med seg inn i faget, og som det kan bygges videre på, blir her omgjort til mål for opplæringen. I vår lesning har vi kommet frem til at slike substantiverte verb er mye brukt i læreplantekstene om kroppsøving og gir uklart innhold. Dette kan skape uklarheter for lærere som skal konkretisere hva som skal vurderes. 


\section{Oppsummerende refleksjoner}

Spørsmålet vi har stilt, er hva vi får øye på i en analyse av språkbruken i de to læreplantekstene. I vår analyse får vi frem at når faget formuleres i læreplanen, skal det først og fremst gjøre noe med elevene. Dette fordi både høringsutkastet og fastsatt læreplan har stor vekt på substantiverte verb. Vi viser gjennom vår analyse og diskusjon hvordan verbbruken til dels endres gjennom de to læreplantekstene, og dels følger samme mønster der verb blir substantivert. Dette gjelder særlig fagspesifikke substantiverte verb, som deltaking, samspel, praktisering, og som viser til handlinger der innholdet ikke er spesifisert, samtidig som det gir rom for at læreren kan hevde at deltaking, samspel og praktisering er observerbar adferd, noe læreren ser på samme måte som innsats. Fornyelsen i kroppsøving ser slik sett ut til å være rettet mot å gjøre fagets betydning i opplæringen tydeligere. De to læreplantekstene har sterke språklige innslag av en innholdsbasert læreplanmodell $i$ betydningen at undervisningen i faget er subjektet. Vi viser til at når faget får en slik posisjon i læreplanen, kommer elevene mer i bakgrunnen. LK20 skal videreføre og fornye LK06 som er en kompetansebasert læreplanmodell, og fornye fagene i skolen for å gi elevene mer dybdelæring og bedre forståelse av det de lærer (KD, 2017). Vi stiller spørsmål ved om læreplanen for faget er fornyet på en slik måte at lærernes arbeid med faget blir språklig mer tilgjengelig og forståelig for elevene. Vi har gjennom tematiseringen av kunnskapsobjektet i kroppsøving fått frem kroppsøvingsfagets egenart; like lite som den gule fargen kan tas ut av sitronen. kan elev- og lærerkroppen skilles ut fra faget.

Våre resultater viser at hvis en læreplan skal ha betydning for lærernes arbeid med kroppsøving som skolefag, er dette arbeidet avhengig av at lærerne har gjennomtenkt språk og begrepsbruk. Kompetanse er i Fagfornyelsen å tilegne seg og anvende kunnskaper og ferdigheter til å mestre utfordringer og løse oppgaver i kjente og ukjente sammenhenger og situasjoner, og innebærer forståelse og evne til refleksjon og kritisk tenkning (KD, 2017, s. 5). Eleven må selv forstå og kunne gjøre noe med et innhold ut over det at læreren har «sett» en aktivitet. Ifølge våre analyser virker ikke språket i LK20 å være tilstrekkelig gjennomarbeidet til å kunne fungere på denne måten for lærerne eller for elevene. Kanskje har noe blitt borte fra LK06 til LK20 som omhandler eleven som handlende subjekt, som skal være i sentrum i en kompetansebasert læreplan. Selv om det ikke er vårt argument at læreplaner kan oversettes direkte til undervisning, mener vi at språkbruken i læreplanteksten skal kunne gi retning og virke tydeliggjørende for det som er det nye i kroppsøving i LK20. Det faglige bidraget fra denne artikkelen er å tilby en diskusjon om mulighetene som en avklaring av språk gir i arbeidet med operasjonalisering av kompetansemålene i læreplanen. Vi argumenterer for at en vedvarende diskusjon om språk og faglige begreper er en sentral del av forvaltningen av kroppsøvingsfaget i både utdanning, forskning og praksis. Dette gjør læreplananalyse til et viktig element i kroppsøving. 


\section{Om forfatterne}

Jorunn Spord Borgen er professor i de praktiske og estetiske fagenes pedagogikk ved Institutt for lærerutdanning og friluftsliv, Norges Idrettshøyskole. Hun er utdannet som faglærer, har kunstfaglig utdanning og doktorgrad fra Det humanistiske fakultet, Universitetet i Bergen. Hun har særlig kompetanse innenfor de praktiske og estetiske fagene, utdanningsforskning, og profesjonskvalifisering.

Institusjonstilknytning: Institutt for lærerutdanning og friluftsliv, Norges idrettshøyskole.

E-post: jorunn.spord.borgen@nih.no

Gunn Engelsrud er professor ved Institutt for idrett, kosthald og naturfag, Fakultet for lærarutdanning, kultur og idrett, Høgskulen på Vestlandet. Hun er utdannet som både fysioterapeut og kroppsøvingslærer og har doktorgrad fra Det samfunnsvitenskapelige fakultet ved Universitetet i Oslo fra 1992. Hun har særlig kompetanse innen kvalitativ forskning, fenomenologi, utforskende bevegelsespraksis, kjønn, mangfold og kroppsforståelser, samt forskning om undervisning og læring i høyere utdanning.

Institusjonstilknytning: Institutt for idrett, kosthald og naturfag. Fakultet for lærarutdanning, kultur og idrett, Høgskulen på Vestlandet.

E-post: guen@hvl.no

\section{Referanser}

Andreassen, S.-E. (2016). Forstår vi læereplanen? Doktoravhandling. Tromsø: UiT, Norges Arktiske Universitet.

Annerstedt, C. (2008) Physical education in Scandinavia with a focus on Sweden: a comparative perspective. Physical Education and Sport Pedagogy, 13(4), 303-318. https://doi.org/10.1080/17408980802353347

Barker, D. M., Aggerholm, K., Standal, O. \& Larsson, H. (2018). Developing the practising model in physical education: an expository outline focusing on movement capability. Physical Education and Sport Pedagogy, 23(2), 209-221. https://doi.org/10.1080/17408989.2017.1371685

Borgen, J. S. \& Engelsrud, G. (2015). Hva skjer i kroppsøvingsfaget? Bedre skole, 2. https://utdanningsforskning.no/artikler/hva-skjer-i-kroppsovingsfaget/

Borgen, J. S. \& Hjardemaal, F. R. (2017). From general transfer to deep learning as argument for practical aesthetic school subjects? Nordic journal of studies in educational policy, 3(3), 218-229. https://doi.org/10.1080/20020317.2017.1352439

Borgen, J. S. (2018). International Comparative Review of Physical Education. OECD Education 2030. In-depth Analysis of Physical Education (PE) in 12 countries. Report prepared under the auspices of the OECD Future of Education and Skills 2030 project. Oslo: Norwegian School of Sport Sciences. 
Borgen, J. S., Hallås, B. O., Løndal, K., Moen, K. M. \& Gjølme, E. G. (2020). Problems created by the (un)clear boundaries between physical education and physical activity health initiatives in schools. Sport, Education and Society. https://doi.org/10.1080/13573322.2020.1722090

Bratberg, Ø. (2017). Tekstanalyse for samfunnsvitere (2. utgave). Oslo: Cappelen Damm Akademiske.

Dale, E. L., Engelsen, B. U. \& Karseth, B. (2011). Kunnskapsløftets intensjoner, forutsetninger og operasjonaliseringer: En analyse av en lcereplanreform. Sluttrapport. Pedagogisk forskningsinstitutt, Universitetet i Oslo.

Dale, E. L. (2008) Fellesskolen - skolefaglig lcering for alle. Oslo: Cappelen Akademisk forlag.

Fauskanger, J. \& Mosvold, R. (2014). Innholdsanalysens muligheter i utdanningsforskning. Norsk pedagogisk tidsskrift, 98(02), 127-139.

Johannessen, L. E. F, Witsø Rafoss, T. \& Børve Rasmussen, E. (2018). Hvordan bruke teori? Oslo: Universitetsforlaget.

Jonskås, K. (2010). En kunnskapsoversikt over FOU-arbeid innen kroppsøvingsfaget i Norge fra januar 1978 - desember 2010. Oslo: Norges Idrettshøgskole.

Karseth, B. \& Sivesind, K. (2010). Conceptualising Curriculum Knowledge Within and Beyond the National Context. European Journal of Education, 45(1), 103-120. https://doi.org/10.1111/j.1465-3435.2009.01418.x

KD (2017). Strategi for fagfornyelsen av Kunnskapsløftet og Kunnskapsløftet samisk. Oslo: Kunnskapsdepartementet.

KD (2018). Retningslinjer for utforming av nasjonale og samiske læereplaner for fag i LK20 og LK20S. Til bruk for læreplangrupper som er oppnevnt av Utdanningsdirektoratet eller Sametinget. Fastsatt av Kunnskapsdepartementet i samråd med Sametinget 26. juni 2018, revidert 10. oktober 2018. Oslo: Kunnskapsdepartementet.

KD (2020). Nye eksamensordninger sendes ut på høring. Pressemelding nr 5-20. Oslo: Kunnskapsdepartementet. https://www.regjeringen.no/no/aktuelt/nye-eksamensordningersendes-ut-pa-horing/id2685570/

Kirk, D. (2010). Physical education futures. London: Routledge.

Larsson, H. \& Karlefors, I. (2018). Searching for the 'How': Teaching methods in Swedish physical education. Scandinavian Sport Studies Forum, 9, 25-44.

Larsson, H. \& Nyberg, G. (2017). 'It doesn't matter how they move really, as long as they move.' Physical education teachers on developing their students' movement capabilities. Physical Education and Sport Pedagogy, 22(2), 137-149. https://doi.org/10.1080/17408989.2016.1157573

Leirhaug, P. E. \& Annerstedt, C. (2016). Assessing with new eyes? Assessment for learning in Norwegian physical education. Physical Education and Sport Pedagogy, 21(6), 616631. https://doi.org/10.1080/17408989.2015.1095871

Lindgren, R. \& Barker, D. (2019). Implementing the Movement-Oriented Practising Model (MPM) in physical education: empirical findings focusing on student learning. Physical Education and Sport Pedagogy, 24(5), 534-547. https://doi.org/10.1080/17408989.2019.1635106

López-Pastor, V. M., Kirk, D., Lorente-Catalán, E., MacPhail, A. \& Macdonald, D. (2013). Alternative assessment in physical education: A review of international literature. Sport, Education and Society, 18(1), 57-76. https://doi.org/10.1080/13573322.2012.713860

Lyngstad, I., Flagestad, L., Leirhaug, P. E. \& Nelvik, I. (2011). Kroppsøving i skolen. Rapport fra arbeidsgruppe i kroppsøving på oppdrag for Utdanningsdirektoratet. Oslo: Utdanningsdirektoratet. 
Mattsson, T. (2016). Expressiva dansuppdrag: utmanande läruppgifter i ämnet idrott och hälsa. Doktoravhandling. Malmø Universitet. Malmø: Bokforlaget Idrottsforum.org.

Nettverk for forskning på kroppsøving og idrettsfag (NFKI) (2019). Oversikt over publisert forskning på kroppsøving, idrettsfag og kroppsøvingslcrerutdanning - fra og med 2010. Oslo: Nettverk for forskning på kroppsøving og idrettsfag.

OECD (2018). The Future of Education and Skills. Education 2030. Paris: OECD.

Penney, D. \& Chandler, T. (2000). Physical Education: What Future(s)? Sport, Education and Society, 5(1), 71-87. https://doi.org/10.1080/135733200114442

Prøitz, T. S. (2015). Lœringsutbytte. Oslo: Universitetsforlaget.

Schwartz, M. (2006). For whom do we write the curriculum? Journal of Curriculum Studies, 38(4), 449-457. https://doi.org/10.1080/00220270500296606

Sivesind, K. (2010). PISA og den bakvendte visa. Bedre skole, 06.06.2010. https://utdanningsforskning.no/artikler/pisa-og-den-bakvendte-visa/

Sivesind, K., Afsar, A. \& Bachmann, K. E. (2016). Transnational policy transfer over three curriculum reforms in Finland: The constructions of conditional and purposive programs (1994-2016). European Educational Research Journal, 15(3), 345-365. https://doi.org/10.1177/1474904116648175

Skrede, J. (2017). Kritisk diskursanalyse. Oslo: Cappelen Damm Akademisk.

Thomassen, M. (2020). Hermeneutikk som refleksjon og livsfortolkning. I D. Jenssen, M. Kjørstad, S. Seim \& P. A. Tufte (red.), Vitenskapsteori og metode for sosial- og helsefag (s. 162-188). Oslo: Gyldendal.

Tinning, R. (2002). Engaging Siedentopian Perspective on Content Knowledge for Physical Education. Journal of teaching in Physical Education, 21(4), 378-391.

Tyler, R. W. (1999/1949). Grunnprinsipper for læreplan og undervisning. I E. L. Dale (red.) (1999), Skolens undervisning og barnets utvikling (s. 81-111). Oslo: Ad Notam Gyldendal.

Udir (2019a). Høring - læreplan i kroppsøving. Oslo: Utdanningsdirektoratet, 18. mars 2019. https://hoering.udir.no/Hoering/v2/342

Udir (2019b). Lereplan i kroppsøving. Fastsatt som forskrift av Kunnskapsdepartementet 15.11.2019. Gjeld frå 01.08.2020. Oslo: Utdanningsdirektoratet. https://data.udir.no/kl06/v201906/laereplaner-lk20/KRO01-05.pdf

Udir (2015). Rundskriv: Endringer i faget kroppsøving Udir-8-2012, kap. 4 Forskrift til Opplæringsloven. Oslo: Utdanningsdirektoratet. https://www.udir.no/regelverkstolkninger/opplaring/Innhold-i-opplaringen/Udir-8-2012

Öhman, M. (2007). Kropp och makt i rörelse. Doktoravhandling i sosiologi. Örebro Universitet.

Øve (2020). Bokmålsordboka. Universitetet i Bergen og Språkrådet. Hentet fra nettadressen: https://ordbok.uib.no/perl/ordbok.cgi?OPP=\%C3\%B8ve\&ant_bokmaal=5\&ant_nynorsk= 5\&begge $=+$ \&ordbok=begge

Aasland, E. (2019). Konstitueringen av “kroppsøving” - En diskursteoretisk studie av undervisningspraksiser i videregående skole. Doktoravhandling. OsloMet storbyuniversitetet.

Aasland, E. \& Engelsrud, G. (2017). «Det er lett å se hvem av dere som har god innsats». Om elevers innsats og lærerens blikk i kroppsøving. Journal for Research in Arts and Sports Education, 1(3), 5-17. https://doi.org/10.23865/jased.v1.889 